\title{
Evaluación del impacto ambiental del uso de nanopartículas de alúmina como aditivo de mezclas biodiesel/diésel mediante análisis de ciclo de vida
}

CHEMICAL ENGINEERING

\section{Environmental impact study by life cycle assessment of the use of alumina nanoparticles as an additive in biodiesel/diesel blends}

\author{
Karina A. Ojeda*§, Adriana P. Herrera*, María J. Sierra*, Katherine Tamayo* \\ *Programa de Ingeniería Química, Facultad de Ingeniería, Universidad de Cartagena. Cartagena, \\ Colombia. \\ §kojedad@unicartagena.edu.co,aherrerab2@unicartagena.edu.co,mjsierra319@hotmail.com, \\ kathetamayos@gmail.com
}

(Recibido: Febrero 2 de 2015 - Aceptado: Abril 14 de 2015)

\begin{abstract}
Resumen
El Análisis de Ciclo de Vida (ACV) de un producto o proceso considera toda su historia, desde su origen como materia prima hasta su final como residuo. En este trabajo, se empleó la metodología ACV para evaluar el impacto ambiental por el uso de nanopartículas de alúmina como aditivo de mezclas de biodiesel-diésel, considerando la síntesis de nanopartículas de alúmina a partir del método sol-gel. La evaluación de cada etapa del proceso se realizó mediante el software SIMAPRO (método CML), para la determinación del potencial de impactos de cada una de las fases en estudio. Aunque el uso de las nanopartículas generó una reducción de las emisiones de $\mathrm{CO} 2, \mathrm{SO} 2$ y material particulado (MP), se observó un incremento en la mayoría de las categorías de impacto (acidificación, eutrofización y eco-toxicidad acuática marina) durante la combustión, debido al aumento en las emisiones de NOx y el efecto tóxico de la fabricación de las nanopartículas, comparado con la combustión sin el nano-aditivo, lo cual plantea el interrogante sobre si el uso de nanotecnología integrada a la industria de biocombustibles representa una alternativa realmente renovable.
\end{abstract}

Palabras Claves: $A C V$, biodiesel, combustión, nanopartículas de alúmina.

\begin{abstract}
Life cycle assessment (LCA) considers the whole life cycle of a product or process, from the origin of the raw materials up to the final disposition of the wastes. In this work, LCA methodology was applied in the evaluation of the environmental impact that is caused by the use of alumina nanoparticles as an additive in biodiesel/diesel blends, considering the synthesis of the alumina nanoparticles through sol-gel method. SIMAPRO software (CML method) was used to evaluate the potential impacts of each stage of the process. Although the use of the nanoparticles caused a reduction in the emissions of $\mathrm{CO}_{2}, \mathrm{SO}_{2}$ and particulate material (PM); an increase in most of the impact categories (acidification, eutrophication and marine eco-toxicity) was observed during combustion. This can be attributed to the increasing emissions of $\mathrm{NO}_{\mathrm{x}}$ and the toxic effect related to the synthesis of the nanoparticles, when compared to combustion without nano-additive. These results indicated that there is a need to carry further research on the use of nanoadditives in biofuels, to verify the renewability of these alternatives regarding the sustainability of the process.
\end{abstract}

Key words: Alumina nanoparticles, biodiesel, combustion, LCA. 


\section{Introduction}

Worldwide tendency on the search for new energetic alternatives has promoted the development of biofuels as a possible solution for the depletion of petroleum. At a national level, biodiesel is one of the biofuels that has been on the rise recently. This can be evidenced when comparing the 163.7 thousand tons that were produced in 2009 with the 448.8 thousand tons in 2012 (Fedebiocombustibles, 2012). A growing tendency is expected in the years to come. Biofuels such as biodiesel can be total of partial substitutes of fossil fuels and they can become a new income source for agriculture. However, high environmental and socio-economic impacts in the production of biodiesel are complicated issues being critically discussed in today's sustainability schemes (Consorcio CUE, 2012). Emissions caused by the use of biodiesel and the fact that its performance is lower than the one of petroleum diesel, represent topics that are still under consideration.

It is important to notice that despite the advantages of biodiesel, this fuel continues to be used along with fossil fuels, and more specifically with petroleum diesel. Although contaminant emissions caused by fuel combustion are reduced when using biodiesel, they cannot be completely eliminated. In the particular case of soot emissions from incomplete combustion, which worsen the greenhouse effect, they can be reduced in a much easier way than the ones from carbon dioxide by using additives that promote complete combustion (Soutter, 2012).

Fuel additives increase biodiesel competitiveness by improving fuel consumption and reducing greenhouse emissions (Park et al., 2007). Ganesh \& Gowrishankar (2011) studied the effect of adding magnalium (Al-Mg) and cobalt oxide $\left(\mathrm{Co}_{3} \mathrm{O}_{4}\right)$ nanoparticles to Jatropha biodiesel at a concentration of $100 \mathrm{mg} / \mathrm{L}$. These nano-additives were able to achieve a maximum reduction of $60 \%$ of unburned hydrocarbons, $50 \%$ of carbon monoxide and $45 \%$ of $\mathrm{NO}_{\mathrm{x}}$ emissions (Ganesh \& Gowrishankar, 2011).

It has been found that alumina nanoparticles improve engine performance and reduce exhaust emissions (Kao et al. 2008), but they can also generate environmental problems when expelled through the flue gases. Thus, an assessment on the possible impacts of the release of these nanoadditives to the environment is essential, as much as a comparison between the potential improvements regarding emissions (Soutter, 2012).

Methodological tools dealing with the environmental assessment of biofuels production have already been reported (Consorcio CUE, 2012). Nevertheless, synthesis of nanoparticles has not been integrated to the lifecycle of the fuel that is currently being used in Colombia (B10). Therefore, the present work is performed according to Life Cycle Assessment methodology, and it focuses on the environmental evaluation of such alternative. This allows the identification of opportunities to integrate different development areas to prevent contamination and reduce resource consumption.

\section{Methodology}

The environmental impact of the use of nanoparticles as additives in diesel/biodiesel blends was assessed by means of a cradle-to-grave methodology. This analysis is based on ISO 14040:2006 regulation (International Organization for Standardization, 2006), which divides Life Cycle Assessment into four stages, as illustrated in Figure 1.

\subsection{Quantification of the environmental impacts of the process}

The first stage is also known as Life Cycle Inventory (LCI)anditconsistsindatacollectionand structuration in order to quantify all of the environmental loads that are associated to the functional unit (Castells \& Montero, 2004) (International Organization for Standardization, 2006).

In this study the functional unit was defined as the energy that is produced when $1 \mathrm{~kg}$ of diesel fuel blend with $10 \%$ biodiesel and nanoparticles $\left(\mathrm{Al}_{2} \mathrm{O}_{3}\right)$ at 10 and $20 \mathrm{ppm}$ is consumed.

The system under study was subdivided into the following process units: (i) synthesis of alumina nanoparticles; (ii) biodiesel production; (iii) 


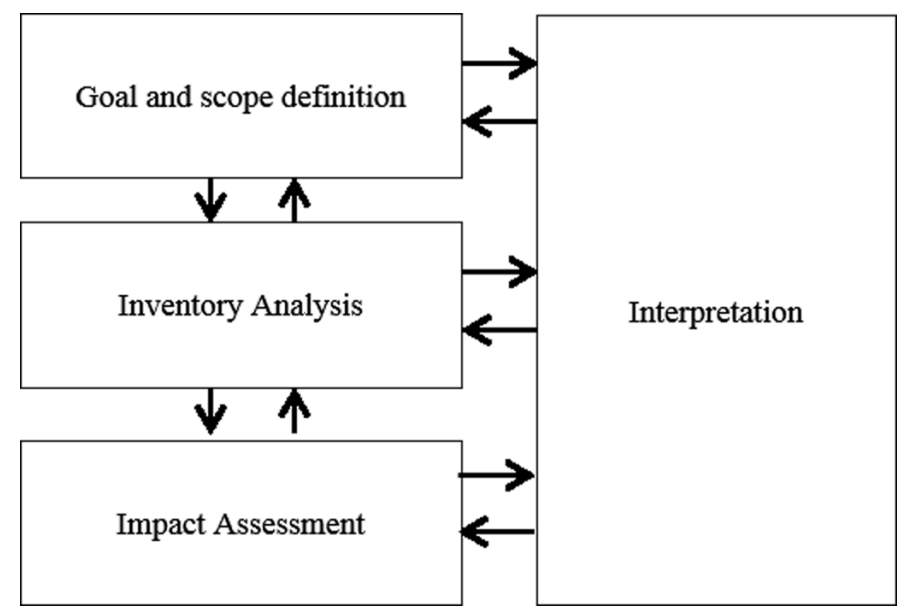

Figure 1. Stages of the LCA according to ISO 14040:2006 regulation.

addition of alumina nanoparticles to the biodiesel/ diesel blend; and (iv) combustion. Inlets, outlets, products and byproducts were defined for each stage, expressed on the basis of the functional unit.

\subsection{Selection of impact categories, indicators and models}

Selection of the impact categories that represented the largest contribution to the environmental consequences that are studied in this work was executed in accordance to ISO 14044:2006 regulation (International Organization for Standardization, 2006).

An impact category is defined as a class that represents the environmental consequences caused by processes of product systems. Table 1 summarizes some of the main impact categories in Life Cycle Analysis (Castells \& Montero, 2004) (International Organization for Standardization, 2006).

Calculations for these categories were made using the SIMAPRO software, its ECOINVENT database (Goedkoop et al., 2008) and Leiden University's model of Environmental Sciences (CML).

\subsection{Impact Assessment of the process}

In this stage, the results of the inventory analysis and environmental impact were combined, in order to determine the stage of the LCA study in which the main environmental impacts are generated. This allows the identification of critical stages that could be improved (Castells \& Montero, 2004).

\section{Results and discussion}

\subsection{Life cycle inventory}

Life cycle inventory of the case study (Figure 2) was performed using mass and energy inputs, products, byproducts, wastes and air, ground and water emissions. All of the data was expressed in terms of the functional unit of reference.

Biodiesel inventory was obtained from the official reports provided by the Ministry of Mines and Energy of Colombia. This information is based on the average biodiesel production process in the northern area of Colombia, from moment the biomass is harvested, up to the refining stage (Consorcio CUE, 2012). In addition, Ecoinvent database of the Simapro software was used to obtain the inventory of diesel.

\subsection{Inventory of the nanoparticles synthesis process}

Inventory data was extracted from the experimental work performed by Peñalosa \& Rincon (2014). 
Table 1. Impact categories

\begin{tabular}{|c|c|c|c|}
\hline Category & \multicolumn{2}{|c|}{ Protection area } & Unit \\
\hline $\begin{array}{l}\text { Abiotic resources } \\
\text { depletion }(A D)\end{array}$ & \multicolumn{2}{|c|}{ Natural resources } & $\mathrm{kg} S b$ \\
\hline $\begin{array}{l}\text { Global warming } \\
\qquad(G W 100)\end{array}$ & \multicolumn{2}{|c|}{ Human health / Natural environment } & $\mathrm{kg} \mathrm{CO}$ \\
\hline \multicolumn{3}{|l|}{$\begin{array}{l}\text { Stratospheric ozone } \\
\quad \text { depletion }(O D)\end{array}$} & $\mathrm{kg} C F C-11$ \\
\hline $\begin{array}{c}\text { Photochemical } \\
\text { oxidant formation } \\
(P O)\end{array}$ & \multicolumn{2}{|c|}{$\begin{array}{l}\text { Human health / } \\
\text { Natural environment / Natural resources }\end{array}$} & kg ethylene \\
\hline Acidification (AC) & \multicolumn{2}{|c|}{$\begin{array}{c}\text { Human health / Natural environment / } \\
\text { Natural resources }\end{array}$} & $\mathrm{kg} \mathrm{SO}$ \\
\hline $\begin{array}{l}\text { Eutrophication } \\
\qquad(E U)\end{array}$ & \multicolumn{2}{|c|}{ Human health / Natural resources } & $\mathrm{kgPO}{ }_{4}^{3-}$ \\
\hline $\begin{array}{l}\text { Human toxicity } \\
\qquad(H T)\end{array}$ & \multicolumn{2}{|c|}{ Human health } & $\operatorname{kg} 1-4 D C B$ \\
\hline \multicolumn{3}{|l|}{$\begin{array}{l}\text { Freshwater aquatic } \\
\text { eco-toxicity (FAET) }\end{array}$} & $\operatorname{kg} 1-4 D C B$ \\
\hline $\begin{array}{c}\text { Marine aquatic } \\
\text { eco-toxicity } \\
(M A E T)\end{array}$ & \multicolumn{2}{|c|}{ Natural environment / Natural resources } & $\operatorname{kg} 1-4 D C B$ \\
\hline $\begin{array}{l}\text { Terrestrial eco- } \\
\text { toxicity (TET) }\end{array}$ & \multicolumn{2}{|c|}{ Natural environment / Natural resources } & $\operatorname{kg} 1-4 D C B$ \\
\hline \multirow[t]{3}{*}{$\begin{array}{l}\mathrm{Bic} \\
\text { proc }\end{array}$} & $\begin{array}{c}\text { Diesel } \\
\text { production }\end{array}$ & $\begin{array}{l}\text { Synthesis of } \\
\text { nanoparticles }\end{array}$ & \\
\hline & Blend & & \\
\hline & Combustion & & \\
\hline
\end{tabular}

Figure 2. Representation of the system of study.

They synthetized alumina nanoparticles through the sol-gel method, which consisted on preparing a citric acid and aluminum nitrate solution in distilled water, with a concentration of $0.5 \mathrm{M}$ of each substance. This solution was placed on a thermal plate with magnetic agitation for 2 hours at $60^{\circ} \mathrm{C}$ until an amber color was achieved (Peñalosa $\&$ Rincon, 2014). Then, it was heated at $80^{\circ} \mathrm{C}$ for an additional 90 minutes, maintaining the constant agitation. The obtained gel was later taken into an oven at $200^{\circ} \mathrm{C}$ in order to eliminate the remaining water content, and it was finally burnt at $1000^{\circ} \mathrm{C}$ for 2 hours (Li et al., 2006).

Ecoinvent database was used to obtain the inventory of the chemical reagents (citric acid and aluminum nitrate) that were involved in the synthesis of alumina nanoparticles. In the 
case of citric acid, a fermentation process using Aspergillus Niger to convert sugar into acid was considered, whereas the reaction between nitric acid and aluminum hydroxide was used for the aluminum nitrate (Eq. 1):

$$
3 \mathrm{HNO}_{3}+\mathrm{Al}(\mathrm{OH})_{3} \rightarrow \mathrm{Al}\left(\mathrm{NO}_{3}\right)_{3}+3 \mathrm{H}_{2} \mathrm{O}
$$

Table 2 shows the inlets and outlets of the production of alumina nanoparticles. This information was evaluated during the synthesis process, which allowed the determination of consumption ratios (energy and mass) and emissions per gram of synthesized nanoparticles.

\subsection{Inventory for the combustion process of the B10 blend with nanoadditives}

Determination of the inventory for the stage of combustion was performed using the Diesels-RK software, developed by the Bauman Moscow State Technical University (BMSTU). The specifications that were used correspond to the diesel engine of a Renault Logan with direct injection, which is one of the most common vehicles in Colombia.

Table 3 presents the inlets of the combustion process for the diesel/biodiesel blend by using a nanoadditive concentration at 10 and $20 \mathrm{ppm}$. Table 4 shows the combustion emissions of this stage after the generation of mechanical energy for the motor has taken place. The combustion gas analyzer for this engine quantified the emissions of $\mathrm{NO}_{x}, \mathrm{CO}_{2}, \mathrm{SO}_{2}$ and particulate matter.

\subsection{Assessment of the impacts of the synthesis of nanoparticles}

Figure 3 shows the environmental impact due to the chemical and biological reagents employed for the synthesis of the nanoparticles, as well as the energy consumption in the equipment, i.e.: agitators and furnaces for drying and calcination of the nanoparticles.

Despite the fact that the energy consumption of the equipment is relatively low, and that this electric energy is supplied by a hydroelectric plant, $\mathrm{CO}_{2}$ and methane emissions are generated by the decomposition of organic matter in the ground and vegetation (due to the creation of artificial dams that are used for the conversion of the mechanical energy of the water into electric energy), which intensifies the problematic of global warming ( $\mathrm{Li}$ \& Zhang, 2014). Additionally, aluminum nitrate production generated nitrogen oxides and sulfur

Table 2. Inlets and outlets for the synthesis of alumina nanoparticles.

\begin{tabular}{|c|c|c|}
\hline & Unit & Quantity \\
\hline \multicolumn{3}{|c|}{ Outlet (product) } \\
\hline Alumina nanoparticles $\left(\mathrm{Al}_{2} \mathrm{O}_{3}\right)$ & $g$ & 1 \\
\hline \multicolumn{3}{|c|}{ Inlet (reagents) } \\
\hline Aluminum nitrate $\mathrm{Al}\left(\mathrm{NO}_{3}\right)_{3}$ & $g$ & 7.98 \\
\hline Citric acid $\mathrm{C}_{6} \mathrm{H}_{8} \mathrm{O}_{7}$ & $g$ & 4.47 \\
\hline \multicolumn{3}{|c|}{ Input (energy consumption) } \\
\hline $\begin{array}{c}\text { Stirring and heating at } 60 \text { y } 80^{\circ} \mathrm{C} \\
\text { (thermal plate) }\end{array}$ & $k W h$ & 5.775 \\
\hline $\begin{array}{c}\text { Heating at } 200^{\circ} \mathrm{C} \text { and } 1000^{\circ} \mathrm{C} \\
\text { (furnace) }\end{array}$ & $k W h$ & 5.92 \\
\hline \multicolumn{3}{|l|}{ Air emissions } \\
\hline Water vapor & $g$ & 253.819 \\
\hline
\end{tabular}


Table 3. Inlet to the combustion system - $1 \mathrm{~kg}$ of fuel

\begin{tabular}{cccc}
\hline Engine inlet & B10 & $\begin{array}{c}\text { B10/ } \\
\text { 10 ppm } \\
\text { nanoadditives }\end{array}$ & $\begin{array}{c}\text { B10/ } \\
\text { 20 ppm } \\
\text { nanoadditives }\end{array}$ \\
\hline Biodiesel $(\mathrm{kg})$ & 0.1153523 & 0.1153511 & 0.1153498 \\
Diesel $(\mathrm{kg})$ & 0.8846476 & 0.8846380 & 0.8846284 \\
NP $(\mathrm{g})$ & 0 & 0.0108133 & 0.0216264 \\
TOTAL $(\mathrm{kg})$ & 1 & 1 & 1 \\
\hline
\end{tabular}

Table 4. Outlet of the combustion system - $1 \mathrm{~kg}$ of fuel.

\begin{tabular}{cccc}
\hline $\begin{array}{c}\text { Outlet } \\
\text { emissions }\end{array}$ & B10 & $\begin{array}{c}\text { B10/ } \\
\text { 10ppm } \\
\text { nanoadditives }\end{array}$ & $\begin{array}{c}\text { B10/ } \\
\text { 20ppm } \\
\text { nanoadditives }\end{array}$ \\
\hline $\begin{array}{c}\text { Particulate } \\
\text { Matter, } \text { PM }^{*}\end{array}$ & 0.1518614 & 0.1489162 & 0.1406362 \\
$\mathrm{CO}_{2}{ }^{*}$ & 3177.8327 & 3159.2435 & 3139.6619 \\
$\mathrm{NOx}^{*}$ & 38.324022 & 40.160220 & 41.9197695 \\
$\mathrm{SO}_{2}{ }^{*}$ & 0.0118128 & 0.0112197 & 0.01042063 \\
\hline *g/kg of consumedfuel & & &
\end{tabular}

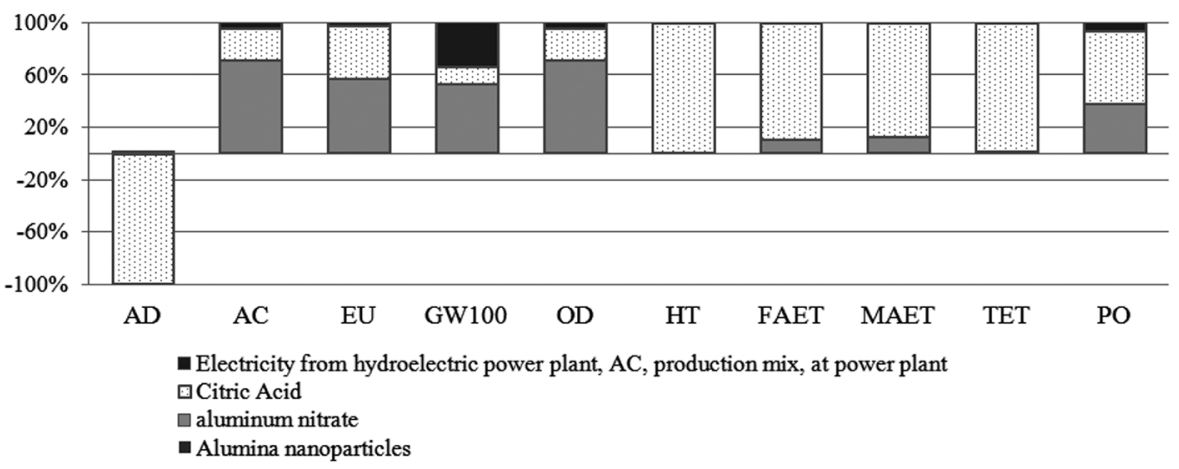

Figure 3. Characterization-production of $1 \mathrm{~kg}$ of alumina nanoparticles (Source: Author's own elaboration using Simapro).

oxides emissions. Both of these substances greatly contribute to the stage of acidification, since they are the cause of acid rain (Goedkoop et al., 2008).

In the same way, this analysis proved that production of citric acid generates environmental consequences on human health and aquatic ecosystems. This is due to the fact that during the processing of this organic acid a considerable amount of emissions containing mercury, lead, benzene, arsenic, radium and sulfur compounds are released to the atmosphere. The presence of these compounds in the air and in water bodies can cause harmful effects such as lung cancer (ETH Zurich \& EPF Lausanne, 2014). Furthermore, this analysis evidenced a negative impact on the category of abiotic resources. This represents a positive contribution to the environment, since the use of a microorganism to produce citric acid involves savings in resource consumption and shows the beneficial effect that could be achieved by using green chemistry and biological resources when obtaining nanoparticles. 


\subsection{Assessment on the impacts of the combustion process}

The last stage involved the evaluation of the combustion process for the biodiesel/diesel blend (B10) with addition of $10 \mathrm{ppm}$ of alumina nanoparticles. Results of the simulated combustion process using the Diesel-RK software were considered from the corresponding data of the physicochemical properties of the nanoparticle modified blend, which were established both experimentally and using models for the prediction of properties (Benjumea et al., 2008).

Figure 4 shows the characterization of the combustion process of the biodiesel/diesel blend in the presence of alumina nanoparticles. From this figure it was determined that the generation of mechanical energy contributes to the environmental impacts in the stages of acidification, eutrophication and global warming. The emission of combustion gases such as nitrogen oxides, sulfur dioxide and particulate matter is the main reason that causes this phenomenon. Such a release modifies the natural concentration of these compounds in the atmosphere, which leads to negative consequences that are caused by a perturbation of the environmental equilibrium.

It is important to note that the use of alumina nanoparticles considerably affects human health, not only because of the fact that it influences the combustion process, but also because of the impact that the synthesis of the nanomaterial exerts on the categories of ground eco-toxicity and depletion of abiotic resources (Figure 4). Regarding the effect of biodiesel on the analyzed life cycle, it is evident that its main influence lies on the eutrophication category that is caused by the agricultural origin of this biofuel, along with the use of fertilizers for the cultivation of biomass. On the other hand, since diesel is the predominant component in the fuel blend, it generated an impact in all of the categories, and especially in the depletion of both abiotic resources and ozone layer. High emissions of contaminant gases to the atmosphere are the cause of this problem, which also accelerates climate change.

\subsection{Comparison between combustion at 0,10 and $20 \mathrm{ppm}$ of alumina nanoparticles}

In order to understand the behavior of the combustion stage at an environmental approach, a comparison of the combustion of the blend (B10) with 0,10 and $20 \mathrm{ppm}$ of alumina nanoparticles was developed (Figure 5). The results show an increasing in most of the impact categories of combustion in the presence of nanoparticles (10 and $20 \mathrm{ppm}$ ), due to the fact that $\mathrm{NO}_{\mathrm{x}}$ emissions increase when compared to combustion without additive. Depletion of abiotic resources and global warming were the only categories that did not exhibited such behavior. This increasing in the $\mathrm{NO}_{\mathrm{x}}$ emissions can be explained by considering the high content of vegetable oils that compose the biodiesel in the blend. Those organic compounds present large amounts of oxygen in their molecular structure, which facilitates the formation of $\mathrm{NO}_{x}$. In addition, the presence of nanoparticles promotes the increasing of such emissions because of the catalytic activity that the nanomaterial exerts

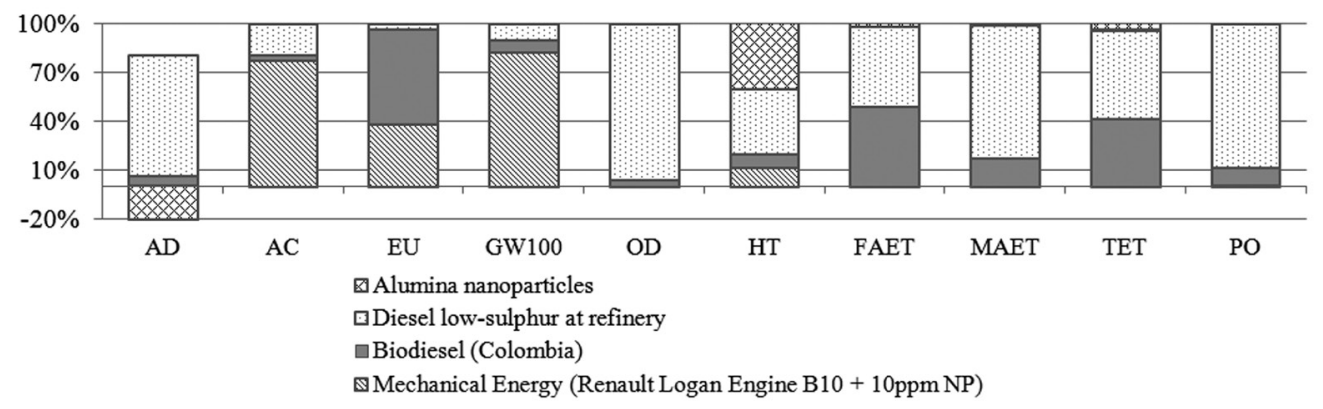

Figure 4. Characterization of the combustion-consumption process of $1 \mathrm{~kg}$ of fuel (Source: Author's own elaboration using Simapro). 


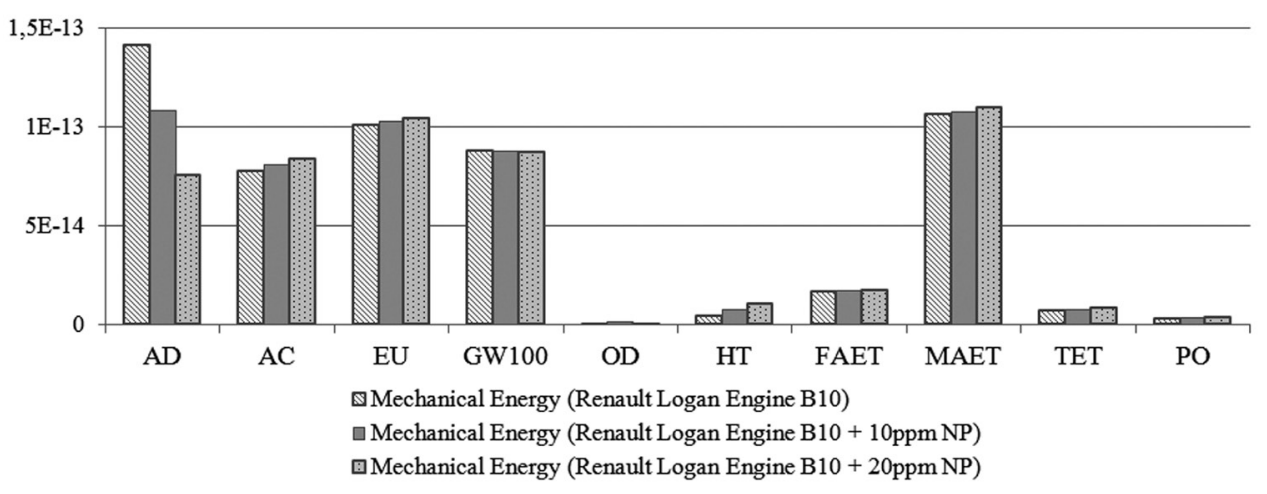

Figure 5. Comparison between combustion of the B10 blend with 0, 10 and 20 ppm of nanoparticles-Normalization (Source: Author's own elaboration using Simapro).

during the reaction between fuel and air at high temperatures (Basha \& Anand, 2009).

Combustion with nanoparticles evidenced a decreasing in the emissions of particulate matter, $\mathrm{CO}_{2}$ and $\mathrm{SO}_{2}$, along with an increasing of $\mathrm{NO}_{x}$, according to the results reported by Mehta et al. (2014). They investigated the combustion of diesel with metallic nanoparticles. The increasing of $\mathrm{NO}_{x}$ emissions greatly contributed to the acidification, eutrophication and marine eco-toxicity categories. Acidification is a consequence of the release of larger quantities of nitrogen oxide that causes the formation of nitric acid, which in turn gets deposited on the ground and in water bodies by the action of rain. Marine ecosystems, soils, and living organisms that inhabit those places get affected in this way.

A positive environmental impact was observed in this analysis due to the consideration that the citric acid was obtained from biomass, when compared to the others chemical reagents used for the synthesis of the alumina nanoparticles. This suggests that the use of natural origins reagents such as vitamins, sugars, plant extracts, biodegradable polymers and microorganisms, along with the implementation of an eco-friendly process (Iravani, 2011), could reduce the levels of toxicity in the final product and the environmental impact of the byproducts, when compared to the conventional method that was selected (Carma, 2012).

\section{Conclusions}

The use of citric acid and aluminum nitrate in the sol-gel method for the synthesis of alumina nanoparticles generated environmental impacts on the integrity of ecosystems and human health categories. However, a positive effect on the category of depletion of abiotic resources was observed, since production of citric acid was considered from a fermentation process by Aspergillus Niger, which causes a reduction in resource consumption.

Combustion of the biofuel/fuel blend (B10) in the presence of nanoadditives releases a great amount of nitrogen oxides, which increases the levels of acidification and eutrophication. Nevertheless, the use of nanoparticles causes a reduction in the emissions of $\mathrm{CO}_{2}, \mathrm{SO}_{2}$ and particulate matter (PM), when compared to the combustion of the Colombian commercial blend without additive. The LCA methodological tool proved that even when innovations regarding additives are applied and fossil fuel (diesel) is still being used at a higher proportion, most of the environmental consequences will be influenced by the extraction and refining processes of oil. This fact dismisses the environmental advantages that nanoparticles have when used as catalyzers for the combustion reaction.

Therefore, evaluation of the alumina nanoparticles in higher concentrations that those studied in this paper is recommended for future researches on this topic. Such information would allow determining whether or not the typical emissions from the combustion of fuel blend increase when the concentration of nanoparticles is varied. In the same way, an assessment should be performed on different case scenarios where concentration of the additive and composition of the biofuel in the blend are modified. 
Conditions rendering the lowest ecological footprint could be predicted in this way. These complementary analyses may help corroborate if the expected environmental contribution of adding nanoparticles to the fuel blend is proportional to the requirements related to engine performance. Implementation of the nanomaterial as a fuel additive relies on such requirements.

\section{Acknowledgements}

The authors would like to express their gratitude to the University of Cartagena and the Chemical Engineering Program for allowing the use of the Material Science Laboratory for the synthesis of the nanomaterials. We would also like to give thanks to COLCIENCIAS, and to Andrés Peñalosa Trujillo, Andy Rincón Ortiz and Mauricio Heras for their support during the development of this project.

\section{References}

Basha, J. \& Anand, R. B. (2009). Performance and emission characteristics of a DI compression ignition engine using carbon nanotubes blended diesel Alexandria Engineering Journal. 53 (2), 259-273.

Benjumea, P., Agudelo, J. \& Agudelo, A. (2008). Basic properties of palm oil biodiesel-diesel blends. Fuel 87 (10-11), 2069-2075.

Carma, R. (2012). Greener approach to nanomaterials and their sustainable applications. Current Opinión in Biotecnology 1 (2), 123-128.

Castells, F. \& Montero, J. (2004). Utilización del Análisis de Ciclo de Vida en la Evaluación del Impacto Ambiental del Cultivo Bajo Invernadero Mediterráneo. Tesis de Doctorado para la obtención del título de Doctor en Ingeniería Ambiental. Universidad Politécnica de Catalunya. Barcelona, España.

Consorcio CUE (Consorcio Universitario Euroamericano). (2012). Evaluación del ciclo de vida de la cadena de producción de biocombustibles en Colombia. Capitulo II: Estudio ACV Impacto ambiental: http://www.fedebiocombustibles.com.
ETH Zurich \& EPF Lausanne (2014). Inventory of Citric Acid Production from Aspergillus Niger. Recuperado [4/11/13] desde la base de datos [Ecoinvent] en: http://www.ecoinvent.org/.

Fedebiocombustibles (Federación Nacional de Biocombustibles de Colombia). (2012). Cifras Informativas del Sector Biocombustibles: Biodiesel de Palma de Aceite. Colombia.

Ganesh, D. \& Gowrishankar, G. (2011). Effect of nano-fuel additive on emission reduction in a Biodiesel fuelled CI engine. In Electrical and Control Engineering (ICECE), 2011 International Conference on. Yichang, China p. 3453 - 3459.

Goedkoop, M., Oele, M., Schryver, A. \& Vieira, M. (2008) SimaPro Database Manual (en línea). http://www.pre-sustainability.com/download/ manuals/DatabaseManualMethods.pdf.

Iravani, S. (2011). Green synthesis of metal nanoparticles using plants. Green Chem 13, 2638-2650.

Kao, M., Ting, C., Lin, B. \& Tsung, T. (2008). Aqueous Aluminum Nanofluid Combustionin Diesel Fuel. Journal of Testing and Evaluation 36 (2), 19428-2959.

Li, J., Pan, Y., Xiang, C., Ge, Q. \& Guo, J. (2006). Low temperature synthesis of ultrafine $\alpha-\mathrm{Al} 2 \mathrm{O} 3$ powder by a simple aqueous sol-gel process. Ceramics International 32 (5), 587-591.

Li, S. \& Zhang, Q. (2014). Partial pressure of $\mathrm{CO} 2$ and $\mathrm{CO} 2$ emission in a monsoon-driven hydroelectric reservoir (Danjiangkou Reservoir), China. Ecological Engineering. 71, 401-414.

Mehta, R., Chakraborty, M. \& Parikh, P. (2014). Nanofuels: Combustion, engine performance and emissions. Fuel, 120, 91-97.

Organización Internacional de Normalización (2006). Gestión Ambiental: Análisis de Ciclo de Vida. Principios y marco de referencia. Madrid, España.

Organización Internacional de Normalización 
(2006). Gestión Ambiental: Análisis de Ciclo de Vida. Requisitos y directrices. Madrid, España.

Park, B., Martin, P., Harris, C., Guest, R., Whittingham, A., Jenkinson, P. \& Handley, J. (2007). Initial in vitro screening approach to investigate the potential health and environmental hazards of Envirox ${ }^{\mathrm{TM}}$ - a nanoparticulate cerium oxide diesel fuel additive. Journal of Particle and Fibre Toxicology 4 (12), 1-10.
Peñalosa, A. \& Rincón, A. (2014) Determinación del efecto del uso de nanopartículas de alúmina en mezcla diesel/biodiesel para mejora de propiedades fisicoquímicas y reducción de emisiones. Tesis de Pregrado para la obtención de título de Ingeniero Químico. Facultad de Ingeniería, Universidad de Cartagena, Cartagena, Colombia.

Soutter, W. (2012). Nanoparticles as fuel additives. http://www.azonano.com/article.aspx?ArticleID=3085 